\title{
$\beta$-Amyloid Disrupts Activity-Dependent Gene Transcription Required for Memory through the CREB Coactivator CRTC1
}

\author{
Judit España, ${ }^{1,2,3}$ Jorge Valero, ${ }^{1,2,3 *}$ Alfredo J. Miñano-Molina, ${ }^{1,2,3 *}$ Roser Masgrau, ${ }^{1,2}$ Elsa Martín,, ${ }^{1,2,3}$ \\ Cristina Guardia-Laguarta, ${ }^{3,4}$ Alberto Lleó, ${ }^{3,4}$ Lydia Giménez-Llort, ${ }^{1,5}$ José Rodríguez-Alvarez, ${ }^{1,2,3}$ \\ and Carlos A. Saura ${ }^{1,2,3}$ \\ ${ }^{1}$ Institut de Neurociències, ${ }^{2}$ Departament de Bioquímica i Biologia Molecular, ${ }^{3}$ Centro de Investigación Biomédica en Red Enfermedades \\ Neurodegenerativas (CIBERNED), ${ }^{4}$ Hospital de la Santa Creu i Sant Pau, and ${ }^{5}$ Departament de Psiquiatria i Medicina Legal, Universitat Autònoma de \\ Barcelona, Barcelona, Spain 08193
}

Activity-dependent gene expression mediating changes of synaptic efficacy is important for memory storage, but the mechanisms underlying gene transcriptional changes in age-related memory disorders are poorly understood. In this study, we report that gene transcription mediated by the cAMP-response element binding protein (CREB)-regulated transcription coactivator CRTC1 is impaired in neurons and brain from an Alzheimer's disease $(\mathrm{AD})$ transgenic mouse expressing the human $\beta$-amyloid precursor protein $\left(\mathrm{APP}_{\mathrm{Sw}, \mathrm{Ind}}\right)$. Suppression of CRTC1-dependent gene transcription by $\beta$-amyloid $(\mathrm{A} \beta)$ in response to cAMP and $\mathrm{Ca}^{2+}$ signals is mediated by reduced calcium influx and disruption of PP2B/calcineurin-dependent CRTC1 dephosphorylation at Ser151. Consistently, expression of CRTC1 or active CRTC1 S151A and calcineurin mutants reverse the deficits on CRTC1 transcriptional activity in $\mathrm{APP}_{\mathrm{SW}, \text { Ind }}$ neurons. Inhibition of calcium influx by pharmacological blockade of L-type voltage-gated calcium channels (VGCCs), but not by blocking NMDA or AMPA receptors, mimics the decrease on CRTC1 transcriptional activity observed in $\mathrm{APP}_{\mathrm{S}, \text { Ind }}$ neurons, whereas agonists of L-type VGCCs reverse efficiently these deficits. Consistent with a role of CRTC1 on A $\beta$-induced synaptic and memory dysfunction, we demonstrate a selective reduction of CRTC1-dependent genes related to memory (Bdnf, c-fos, and Nr4a2) coinciding with hippocampal-dependent spatial memory deficits in $\mathrm{APP}_{\mathrm{S}_{\mathrm{w}} \text {,Ind }}$ mice. These findings suggest that CRTC1 plays a key role in coupling synaptic activity to gene transcription required for hippocampal-dependent memory, and that $\mathrm{A} \beta$ could disrupt cognition by affecting CRTC1 function.

\section{Introduction}

Gene expression changes in the forebrain occur during normal and pathological aging. Altered gene expression is thought to contribute to the balance between normal aging and age-related memory disorders, including Alzheimer's disease (AD) (Coleman and Yao, 2003; Berchtold et al., 2008). Synaptic dysfunction in AD is apparent before synapse and neuron loss and caused likely by accumulation of $\beta$-amyloid (A $\beta$ ) peptides (Selkoe, 2002). The cellular mechanisms underlying synaptic and memory dysfunction caused by altered activity-dependent gene transcription in $\mathrm{AD}$ are largely unknown. Understanding the molecular pathways regulating gene expression profiles in memory disorders may allow the identification of new signaling pathways for drug discovery (Altar et al., 2009).

\footnotetext{
Received April 27, 2010; accepted May 28, 2010.

This work was supported by grants from the Ministerio de Ciencia e Innovación (SAF2007-64115 and CIBERNED (B06/05/0042), Ministerio de Sanidad (FIS 04/0937 to C.A.S. and FIS 07/1137 to A.L.) and the 7th Framework Programme of the European Commission (MEMOSAD project, Grant 200611). We thank L. Mucke for providing the $A P_{S_{\text {Ww, Ind }}}$ mice, M. Montminy for CREB and CRTC2 plasmids, J.-R. Cardinaux for mCRTC1 plasmid, R. Janknecht for CBP and p300 plasmids, I. Torres-Alemán for $\Delta$ CnA plasmid, and W. Van Nostrand for Ab20.1 antibody. We thank the Servei de Genòmica at the Universitat Autònoma de Barcelona.

*J.V. and A.J.M.-M. contributed equally to this work.

Correspondence should be addressed to Carlos A. Saura, Institut de Neurociències, Facultat de Medicina M2-113, Universitat Autònoma de Barcelona, Barcelona, Spain 08193. E-mail: carlos.saura@uab.es.

DOI:10.1523/JNEUROSCI.2154-10.2010

Copyright $\odot 2010$ the authors $\quad 0270-6474 / 10 / 309402-09 \$ 15.00 / 0$
}

Activity-induced gene transcription mediates long-lasting changes of synaptic efficacy essential for neuronal plasticity and memory (Worley et al., 1993; Guzowski et al., 2001; Kandel, 2001). Thus, gene expression mediated by the transcription factor cAMP-response element binding protein (CREB) is essential for synaptic plasticity and long-term memory (Bourtchuladze et al., 1994; Won and Silva, 2008). CREB transcriptional activation depends on calcium- and cAMP-dependent phosphorylation of CREB at Ser133 (Sheng et al., 1991; Mayr and Montminy, 2001), a process mediated by L-type voltage-gated calcium channels (VGCCs) or glutamate ligand-gated receptors (NMDA and AMPA) (Murphy et al., 1991; Cohen and Greenberg, 2008). Interestingly, altered cAMP/PKA-dependent CREB signaling has been postulated to mediate the effect of $A \beta$ on hippocampal synaptic plasticity, memory, and synapse loss (Vitolo et al., 2002; Gong et al., 2006; Smith et al., 2009).

Selective gene transcription by CREB depends on additional events, including other phosphorylation sites and recruitment of specific coactivators. The CREB-regulated transcription coactivators (CRTCs, also known as TORCs) regulate biological events by integrating cellular signals into gene transcriptional responses. Three members of the CRTC family involved in CREB activation (CRTC1, CRTC2, and CRTC3) have been described in mammals (Iourgenko et al., 2003; Ravnskjaer et al., 2007). In non-neuronal cells, selective expression of CREB target genes in response to cAMP and $\mathrm{Ca}^{2+}$ signals, but not by stress stimuli, is achieved by 
cooperative interaction between CRTC2 and CREB binding protein (CBP)/p300 (Conkright et al., 2003; Ravnskjaer et al., 2007). CRTC1, the most abundant isoform in neurons, mediates the synergistic effect of calcium and cAMP signals on CREBdependent transcription and long-term potentiation (LTP) (Kovács et al., 2007). CRTC activation by $\mathrm{Ca}^{2+}$ and cAMP signals involves its dephosphorylation by the calcium-dependent phosphatase $\mathrm{PP} 2 \mathrm{~B} /$ calcineurin and cAMP-mediated inhibition of saltinducible kinases 1/2 (SIK-1/2) (Bittinger et al., 2004; Screaton et al., 2004; S. Li et al., 2009). Consistent with its role on CREB activation, CRTC1 has been implicated in neuronal dendritic growth, long-term synaptic plasticity, and glucose metabolism (Zhou et al., 2006; Kovács et al., 2007; Altarejos et al., 2008; S. Li et al., 2009).

Whereas the function of CRTC1 on neuronal morphology and plasticity is well established, its role on activity-dependent gene transcription required for memory remains unknown. In this study, we demonstrate that $\mathrm{A} \beta$ negatively regulates CRTC1 activation in cultured primary neurons and brain from $\mathrm{APP}_{\mathrm{Sw}, \mathrm{Ind}}$ transgenic mice, resulting in a selective and differential disruption of CREB-dependent genes required for hippocampaldependent memory.

\section{Materials and Methods}

Plasmids and antibodies. Mouse CRTC1-myc, Flag-CRTC2, CREB, CREB R314A, CBP-HA, and p300-HA cloned in pcDNA were previously described (Janknecht et al., 1998; Conkright et al., 2003; Screaton et al., 2004; Kovács et al., 2007). Mouse calcineurin lacking functional CaMbinding and autoinhibitory domains $(\triangle \mathrm{CnA})$ was cloned in the CMVTag 4A plasmid (O'Keefe et al., 1992). pCRE-luc and TK-Renilla plasmids were purchased from Stratagene and Promega. The CRTC1 S151A mutant was generated from pcDNA3-CRTC1-myc by standard site-directed mutagenesis protocols (Stratagene) with the following forward and reverse primers: 5' -GGAGGAGGACCAACGCTGACTCTGCCCTG-3' and 5' -CAGGGCAGAGTCAGCGTTGGTCCTCCTCC-3' .

Rabbit phospho-Ser151 CRTC1 antibody was generated by immunizing two rabbits with KLH-conjugated ADTSWRRTN(pS)DSALHQSTMT peptide corresponding to mouse/human CRTC1 (amino acids 142-161). The CRTC1-pSer151 antiserum was sequentially purified by ammonium sulfate precipitation and affinity purification (EZBiolab). The following antibodies were used: APP/A $\beta$ (6E10; 1:2000; Signet), CRTC1 (1:1000; Cell Signaling Technology), CREB and pSer133 CREB (1:1000; Cell Signaling Technology), Egr-1 (1:500; Santa Cruz Biotechnology), BDNF (1:500; Alomone Labs), c-fos (1:500; Santa Cruz Biotechnology), lamin B1 (1:500; Zymed), calcineurin (1:500; BD Transduction Labs), c-myc (9E10; 1:1000; Santa Cruz Biotechnology), $\beta$-actin (1:40,000; Abcam), and $\beta$-tubulin (1:20,000; Sigma-Aldrich).

$A P P$ transgenic mice and behavioral test. $\mathrm{APP}_{\mathrm{Sw}, \text { Ind }}$ (line J9) transgenic mice expressing mutant human $\mathrm{APP}_{695}$ isoform harboring the $\mathrm{FAD}$ linked Swedish (K670N/M671L) and Indiana (V717F) mutations under the neuronal PDGF $\beta$ promoter have been previously described (Mucke et al., 2000). Mice were age-matched littermate males obtained by crossing heterozygous $\mathrm{APP}_{\mathrm{Sw} \text {,Ind }}$ to nontransgenic (WT) mice (C57BL/6 background). The Morris water maze was performed as previously described (Giménez-Llort et al., 2007; España et al., 2010). Experimenters of the behavioral tests were blind to the genotypes of the mice. Animal procedures were performed in accordance with institutional and national guidelines following approval by the Animal Care and Ethical Committee (CEEAH) of the Universitat Autònoma de Barcelona.

Primary neuronal culture and luciferase reporter assay. Primary neurons were obtained from mouse embryos (E15.5) of heterozygous $\mathrm{APP}_{\mathrm{Sw}, \text { Ind }} \times$ nontransgenic crossings. Neurons were dissociated and cultured in Neurobasal medium containing 2\% B27, 2 mm glutamine, and 30 mm glucose at a density of $5 \cdot 10^{4}$ cells $/ \mathrm{cm}^{2}$ in 24 -well or 35-60 mm dishes. For luciferase assays, 7-15 d in vitro (DIV) neurons in 24-well dishes were transfected for $24 \mathrm{~h}$ with pCRE-luc $(0.5 \mu \mathrm{g})$, TK-Renilla $(0.25 \mu \mathrm{g})$, and vector or the indicated plasmids $(0.5 \mu \mathrm{g})$ by using LipofectAMINE 2000
(Invitrogen). For interference assays, neurons at day 0 were infected with shRNA lentiviral vectors (1-2 transducing units per cell). Neurons were treated at 7 DIV with the indicated reagents before stimulation with vehicle, $\mathrm{KCl}(30 \mathrm{~mm})$, and/or forskolin (20 $\mu \mathrm{M}$; Sigma) for $4 \mathrm{~h}$. Luciferase activity was measured by triplicate in at least three independent transfections by using the Dual-Luciferase Assay System (Promega) in a Synergy HT luminometer (Bio-Tek).

Lentiviral shRNA and ChIP. Complementary oligonucleotides for mouse CRTC1 shRNA were as follows: Sh-CRTC1 forward: 5' -gatccccGCAGCGTGACAATCGACCTATttcaagagaATAGGTCGATTGTCACGCTGCttttt-3'; Sh-CRTC1 reverse: $5^{\prime}$-agctaaaaaGCAGCGTGACAATCGACCTATtctcttgaaATAGGTCGATTGTCACGCTGCggg- $3^{\prime}$. The scramble control oligonucleotides used were as follows: forward 5' -gatccccGGCTGGGAATGGTAGTCATttcaagagaATGACTACCATTCCCAGCCttttt-3' and reverse: 5'-agctaaaaaGGCTGGGAATGGTAGTCATtctcttgaaATGACTACCATTCCCAGCCggg-3'. Oligonucleotides were cloned into BglII/HindIII sites of the pSUPER.retro.puro plasmid (OligoEngine). Lentiviral vectors were obtained by digesting EcoR1-ClaI sites from pSUPER-Sh to generate the sequence H1-shRNA that was inserted into PLVTHM vector. Lentiviral particles were generated in HEK293T cells transfected with pLVTHM-Sh, pSPAX2, and pM2G vectors.

For chromatin immunoprecipitation (ChIP) assays, cortical neurons (7 DIV) were treated with vehicle or FSK $(20 \mu \mathrm{M})$ plus $\mathrm{KCl}(30$ $\mathrm{mm}$ ) for $2 \mathrm{~h}$. Cells were cross-linked with $1 \%$ formaldehyde, lysed in ChIP buffer (25 mм HEPES, pH 8.0, $1.5 \mathrm{~mm} \mathrm{MgCl}_{2}, 10 \mathrm{~mm} \mathrm{KCl}, 0.1 \%$ NP-40, $1 \mathrm{~mm}$ DTT, and protease and phosphatase inhibitors) and sonicated. Immunoprecipitations of DNA $(2.5 \mu \mathrm{g})$ were performed overnight with anti-CRTC1 or irrelevant IgG (Cell Signaling Technology). PCR amplification was performed with specific primers for CRE-containing promoters of the genes of interest (supplemental Table 1S, available at www.jneurosci.org as supplemental material).

Biochemical assays. Primary neurons or mouse hippocampi were lysed in $0.5 \mathrm{ml}$ of cold-lysis buffer (50 mM Tris- $\mathrm{HCl}$, pH 7.4, $150 \mathrm{~mm} \mathrm{NaCl}, 2$ mм EDTA, 0.5\% Triton X-100, 1\% NP-40, 0.1\% SDS, 1 mu Na $\mathrm{VO}_{4}, 50$ $\mathrm{mM} \mathrm{NaF}$, and $1 \mathrm{~mm}$ PMSF) supplemented with protease and phosphatase inhibitors (Roche). For nuclear fractionation, primary neurons were incubated with the indicated reagents, washed twice in cold-PBS, and lysed using a Dounce homogenizer in buffer A (25 mM HEPES, pH 7.4, $250 \mathrm{~mm}$ sucrose, $10 \mathrm{~mm} \mathrm{KCl}, 1.5 \mathrm{~mm} \mathrm{MgCl}, 1 \mathrm{~mm} \mathrm{Na}_{3} \mathrm{VO}_{4}, 50 \mathrm{~mm} \mathrm{NaF}$, and $1 \mathrm{~mm}$ PMSF, supplemented with protease and phosphatase inhibitors). Homogenate was centrifuged $(1500 \times g)$ at $4^{\circ} \mathrm{C}$ for $15 \mathrm{~min}$. The pellet (nuclei) was washed (twice) in buffer $\mathrm{A}$ and resuspended and sonicated in lysis buffer ( $25 \mathrm{~mm}$ Tris $\mathrm{HCl}, \mathrm{pH} 7.4,150 \mathrm{~mm} \mathrm{NaCl}, 1 \% \mathrm{NP}-40$, and $10 \%$ glycerol) supplemented with protease and phosphatase inhibitors. Proteins were quantified using the BCA protein assay kit (Pierce) and resolved on $8-12.5 \%$ SDS-PAGE gels. Proteins were visualized with the enhanced chemiluminescence ECL kit (PerkinElmer) and quantified with the ImageJ software within a linear range of detection for the ECL reagent (España et al., 2010). Soluble $A \beta$-derived diffusible ligands (ADDLs) were prepared freshly from synthetic $\mathrm{A} \beta_{1-42}$ peptides (Bachem) as previously described (Klein, 2002). The same aggregation protocol was performed on $\mathrm{A} \beta_{42-1}$ peptides. The aggregated $\mathrm{A} \beta$ peptides were negative stained and examined in a JEOL JEM-2011 transmission electron microscope. Human $\mathrm{A} \beta_{1-40}$ and $\mathrm{A} \beta_{1-40}$ peptides were measured in conditioned medium using sensitive sandwich ELISA $\mathrm{A} \beta_{1-40}$ and $\mathrm{A} \beta_{1-42}$ kits (Wako) (Guardia-Laguarta et al., 2009).

Calcineurin activity was determined with the calcineurin cellular activity assay kit (Calbiochem). Briefly, mouse brain or cortical neurons were homogenized in lysis buffer ( $25 \mathrm{~mm}$ Tris- $\mathrm{HCl}, \mathrm{pH} 7.5,0.5 \mathrm{~mm}$ dithiothreitol, $50 \mu \mathrm{m}$ EDTA, $50 \mu \mathrm{m}$ EGTA, and 0.2\% NP-40). Free phosphate was eliminated using a desalting column, and equal amount of protein was incubated with the calcineurin substrate RII phosphopeptide $(1.64 \mathrm{mg} / \mathrm{ml})$ for $30 \mathrm{~min}$ at $30^{\circ} \mathrm{C}$. The reaction was stopped by adding 100 $\mu \mathrm{l}$ of GREEN and fluorescence was measured at $620 \mathrm{~nm}$ using a microtiter plate reader.

Immunostaining of primary neurons. Cortical neurons (10 DIV) were fixed in PBS, pH 7.5, containing 4\% paraformaldehyde, $4 \%$ sucrose, and $50 \mathrm{~mm}$ HEPES for $15 \mathrm{~min}$. Cells were incubated in PBS containing $0.1 \mathrm{M}$ 
glycine, washed in PBS-Tween 0.1\% (PBS-T), and permeabilized with PBS-T plus $0.1 \%$ Triton X-100. Cells were blocked with PBS-T containing $0.5 \%$ normal goat serum, incubated overnight with mouse antiPSD-95 (1:50; BD Bioscience) and rabbit anti-synapsin I (1:500; Sigma) antibodies, and detected with the Alexa Fluor 488 or 594 secondary antibodies (1:500) and Hoechst 33258 (Invitrogen). Images from control and $\mathrm{APP}_{\mathrm{Sw}, \text { Ind }}$ embryonic neurons ( $n=3$ per genotype) were analyzed by confocal laser microscopy (Leica TCS SP2 AOBS; Carl Zeiss). For quantitative analyses, acquired neurite images ( $n \geq 15$ per genotype) were analyzed using LAS AF software (Leica Microsystems). Synaptic boutons were defined as being $0.5-2 \mu \mathrm{m}$ in length, twofold to threefold more intense than background staining, and stained for synapsin, PSD-95, or both synaptic markers. The number of boutons was divided by the length of the selected dendrite and density presented as boutons per unit length.

Calcium imaging. Primary cortical neurons grown onto poly-lysinecoated coverslips for $7 \mathrm{~d}$ were incubated with the calcium indicator Fura2/AM $(4 \mu \mathrm{M})$ for $1 \mathrm{~h}$. Coverslips were washed with Krebs buffer containing (in mM) $119 \mathrm{NaCl}, 4.75 \mathrm{KCl}, 5 \mathrm{NaHCO}_{3}, 1.2 \mathrm{MgSO}_{4}, 1.18$ $\mathrm{KH}_{2} \mathrm{PO}_{4}, 1.3 \mathrm{CaCl}_{2}, 20$ HEPES, and 10 glucose, $\mathrm{pH} 7.4$, and mounted in a static chamber at $37^{\circ} \mathrm{C}$ on an inverted Nikon TE2000U microscope. Cells were excited alternatively at 340 and $380 \mathrm{~nm}$ using a monochromator (Cairn Research Limited), and emission light collected at $510 \mathrm{~nm}$ every $4 \mathrm{~s}$. Images were acquired by using a 12 bit-CCD ERG ORCA Hamamatsu camera and processed with the Metafluor software (Universal Imaging). When appropriated, cells were treated with $\mathrm{KCl}(30 \mathrm{~mm})$ and forskolin $(20 \mu \mathrm{M}) . n \geq 15$ cells/genotype ( $n=3$ embryos) were analyzed in each experiment.

Real-time RT-PCR. Total RNA was isolated from mouse primary cortical neurons or hippocampal tissue using the RNeasy Mini Kit (Qiagen). Purified RNA was reverse transcribed using the SuperScript II Reverse Transcriptase Kit (Invitrogen). Briefly, a reaction mix containing $0.25 \mu \mathrm{g}$ of Oligo(dT) primers, $0.5 \mathrm{~mm}$ dNTP, $0.45 \mathrm{~mm}$ DTT, RNaseOut (10 U), and SuperScript II Reverse Transcriptase (200 U; Invitrogen) was incubated at $25^{\circ} \mathrm{C}$ for $10 \mathrm{~min}, 42^{\circ} \mathrm{C}$ for $60 \mathrm{~min}$, and $72^{\circ} \mathrm{C}$ for $10 \mathrm{~min}$. Quantitative RT-PCR of a reaction mix containing cDNA $(1 \mu \mathrm{l})$, primer pairs (supplemental Table 1S, available at www.jneurosci.org as supplemental material), and the QuantiMix EASY SYG KIT mix (10 $\mu$ l; Biotools) was performed in an ABI PRISM 7900 Sequence Detector (Applied Biosystems). Data analysis was performed by the comparative $\Delta \Delta \mathrm{Ct}$ method using the SDS 2.1 software and normalizing to GAPDH.

Statistical analysis. Statistical analysis was performed using one-way ANOVA and Bonferroni post hoc test. The behavioral data were analyzed using two-way ANOVA with repeated measures and Scheffé's $S$ test for post hoc comparisons. Data were shown as the mean \pm SEM. Differences with $p<0.05$ were considered significant.

\section{Results}

$\mathrm{A} \boldsymbol{\beta}$ impairs CRTC1-dependent gene transcription in neurons To evaluate the possible role of CREB signaling on $A \beta$-induced transcriptional changes underlying memory dysfunction, we first established primary neurons from an $\beta$-amyloid precursor protein $(\mathrm{APP})$ transgenic mouse $\left(\mathrm{APP}_{\mathrm{Sw}, \text { Ind }}\right)$ that develops agedependent amyloid pathology and memory deficits (Mucke et al., 2000; España et al., 2010). Cortical neurons from $\mathrm{APP}_{\mathrm{Sw}, \mathrm{Ind}}$ embryos expressed human APP (approximately twofold) and released soluble $\mathrm{A} \beta_{1-40}$ and $\mathrm{A} \beta_{1-42}$ peptides without causing gross morphological synaptic changes (supplemental Fig. 1S, available at www.jneurosci.org as supplemental material). Confocal microscopy analysis revealed no significant differences on the number of presynaptic (synapsin), postsynaptic (PSD-95), or active (synapsin/PSD-95) synapses (supplemental Fig. 2S, available at www.jneurosci.org as supplemental material). Since synaptic activity induces efficient expression of immediate-early genes in cortical neurons over the course of 1-3 weeks (Murphy et al., 1991), we performed CREB transcriptional analysis in neurons at 7-15 DIV in conditions mimicking the effects of neuronal activity, such as increasing intracellular $\mathrm{Ca}^{2+}$ by depolarizing concentrations of $\mathrm{KCl}(30 \mathrm{~mm})$ or cAMP with the adenylate cyclase activator forskolin (FSK) (Greer and Greenberg, 2008). Treatment of control neurons with FSK or $\mathrm{KCl}$ resulted in $\sim 2$ - and $\sim 7$-fold increase on CRE-luciferase activity, respectively, whereas their combination induced a synergistic effect ( 10-fold) (Fig. 1A). Notably, activation of CRE-dependent transcription was unchanged by FSK but was significantly reduced by $\mathrm{KCl}(\sim 25 \%)$ or $\mathrm{KCl}$ plus FSK $(\sim 50 \%)$ in cortical and hippocampal $\mathrm{APP}_{\mathrm{Sw} \text {,Ind }}$ neurons (Fig. $1 A$ ). Inhibitors of synaptic activity (tetrodotoxin TTX) or calcineurin (FK-506 and cyclosporine) selectively blocked CRE-transcriptional activity induced by $\mathrm{Ca}^{2+}$ and cAMP signals (Fig. $1 A$ ).

Consistent with the idea that CRTC mediates the synergistic effect of cAMP and $\mathrm{Ca}^{2+}$ on CREB-dependent transcription (Screaton et al., 2004), we found that CRTC1, CRTC2, CBP, or p300, but not the CREB R314A mutant lacking the CRTC binding domain (Screaton et al., 2004), potentiated and reversed CRE-transcriptional deficits in $\mathrm{APP}_{\mathrm{Sw} \text {,Ind }}$ neurons (Fig. $1 B$ ). These results suggested a role of CRTC on altered activityinduced CRE-transcription in $\mathrm{APP}_{\mathrm{S}_{\mathrm{w}} \text {,Ind }}$ neurons. We then focused on CRTC1, the most abundant CRTC isoform in neurons and brain (Kovács et al., 2007; Altarejos et al., 2008). We generated lentiviral vectors expressing CRTC1 shRNA that decreased significantly CRTC1 (62-75\%) and CRE-mediated transcription induced by cAMP and $\mathrm{Ca}^{2+}$ signals ( $\left.~ 80 \%\right)$ (Fig. $1 C$ ). To study the biological significance of CREB transcriptional deficits, we analyzed expression of endogenous genes. Genetic inactivation of CRTC1 by shRNA and gene ChIP analyses demonstrated that CRTC1 is recruited to and activates CRE-containing promoters of several genes, including $c-f o s, B d n f I V$, and $N r 4 a 2$ but not Cyr61 (Fig. 1D,E). Interestingly, induced expression of endogenous CRTC1-dependent genes related to synaptic plasticity and memory such as $c$-fos, Bdnf IV, and Nr4a2 ( 100- to 1000-fold), but not Cyr61 ( $\sim 15$-fold), a CREB target gene related to proliferation and activated independently of CRTC1 (Ravnskjaer et al., 2007), was significantly decreased in $\mathrm{APP}_{\text {Sw,Ind }}$ cortical neurons (Fig. 1D).

To test whether $\mathrm{A} \beta$ was responsible for mediating the effect of CRTC1 in $\mathrm{APP}_{\mathrm{Sw} \text {,Ind }}$ neurons, we used pharmacological and genetic approaches previously shown to reduce $\mathrm{A} \beta$ levels (Saura et al., 2005; Oddo et al., 2006). Decreasing A $\beta$ with the $\gamma$-secretase inhibitor DAPT or treatment with an anti-A $\beta$ antibody (Ab20.1) reversed significantly CRE-transcriptional deficits in $\mathrm{APP}_{\mathrm{Sw}, \text { Ind }}$ neurons (Fig. 2A; supplemental Fig. 1S, available at www. jneurosci.org as supplemental material). Surprisingly, affecting only extracellular $\mathrm{A} \beta$ by treatment with Ab20.1 reversed only partially CRE-transcriptional deficits. Furthermore, genetic inactivation of PS1/ $\gamma$-secretase in $\mathrm{APP}_{\mathrm{Sw} \text {,Ind }}$ neurons resulted in normal levels of CRE-transcriptional activity (data not shown). By contrast, media from $\mathrm{APP}_{\mathrm{Sw}, \text { Ind }}$ neurons or soluble globular synthetic $\mathrm{A} \beta_{1-42}$ oligomers (ADDLs) containing dimers, trimers, hexamers, and dodecamers at concentrations not affecting neuron morphology or viability (1-20 $\mu \mathrm{M}$ ) (Klein, 2002), but not $\mathrm{A} \beta_{1-42}$ monomers or $\mathrm{A} \beta_{42-1}$ peptides submitted to the aggregation protocol, reduced significantly CREB-dependent transcription in a dose-dependent manner (Fig. 2B,C). These results suggested that $A \beta$ negatively affects activity-induced CRTC1dependent transcription in primary neurons.

\section{Calcineurin-dependent CRTC1 dephosphorylation and activation are impaired in $\mathrm{APP}_{\mathrm{Sw}, \text { Ind }}$ mice}

The inhibitory effect of calcineurin inhibitors, the CREB R314R mutant, and CRTC1 shRNA on CRTC1 transcription (Fig. 1 A,B) 
A

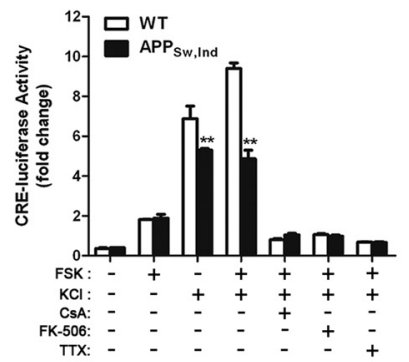

B

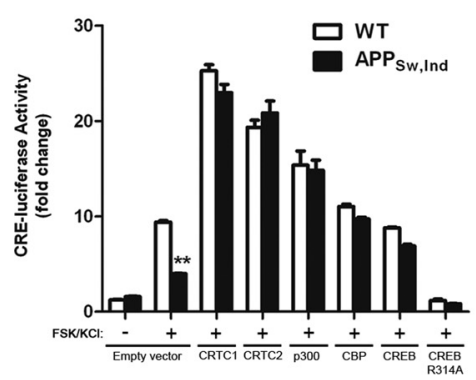

C
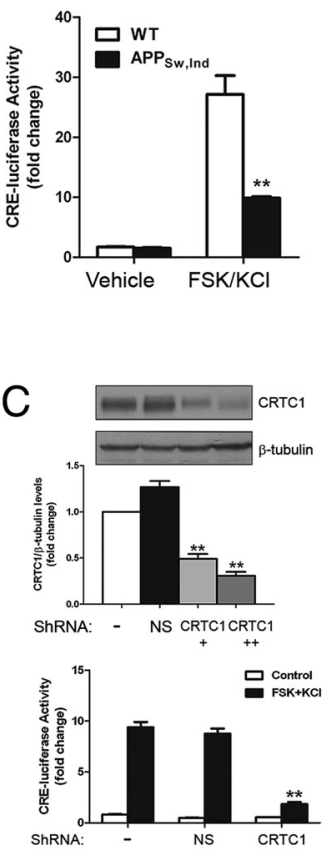

$E$

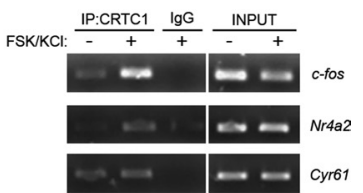

A

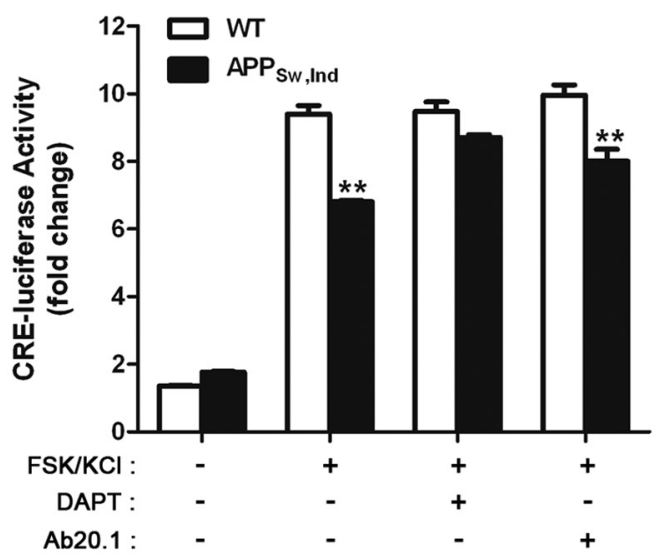

B
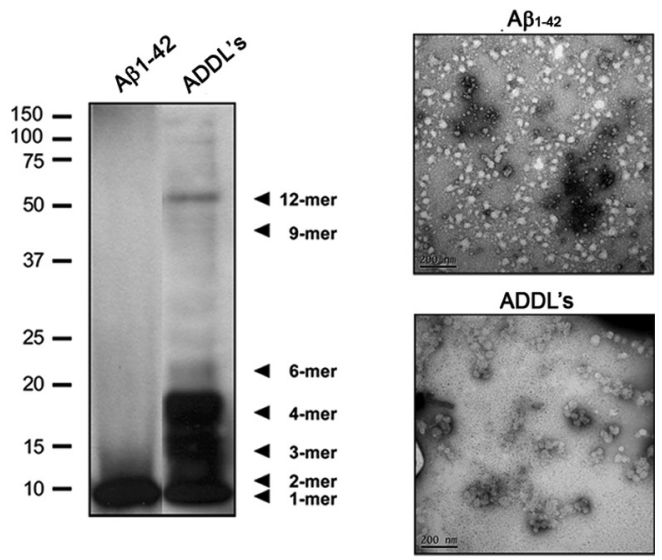

C



Figure 2. $\quad A \beta$ oligomers impair CRTC1-dependent signaling. A, CRE transcriptional activity in primary cortical neurons treated with vehicle (-), DAPT (125 nM), or anti-A $\beta$ antibody (Ab20.1; $1 \mu \mathrm{g}$ ) for $48 \mathrm{~h} . \boldsymbol{B}$, Biochemical (6E10 antibody) and electron microscopy analysis of $A \beta$ species present in soluble monomeric $A \beta_{1-42}$ and ADDL preparations. C, CRE-luciferase activity in cortical neurons treated for $48 \mathrm{~h}$ with vehicle (-), soluble ADDLs (1-30 $\mu \mathrm{M})$, aggregated $A \beta_{42-1}$ $(20 \mu \mathrm{M}), A \beta_{1-42}$ monomers (1 or $\left.20 \mu \mathrm{M}\right)$, or media from control (WT) or APP Sw,Ind $_{\text {nd }}$ neurons. Data represent the mean \pm SEM of three independent transfections performed by triplicate. ${ }^{*} p<$ 0.05 , compared to WT medium; ${ }^{* *} p<0.01$, compared to FSK/KCl-treated neurons.

cineurin mutant $\Delta \mathrm{CnA}$ (O'Keefe et al., 1992) potentiated CRTC1-dependent transcription, only expression of $\triangle \mathrm{CnA}$ reversed efficiently transcriptional deficits in $\mathrm{APP}_{\mathrm{SW}_{\mathrm{w}} \text { Ind }}$ neurons (Fig. $3 A$ ). Biochemical and quantitative analyses revealed that FSK/KCl-induced CRTC1 dephosphorylation was significantly reduced in $\mathrm{APP}_{\mathrm{Sw}, \text { Ind }}$ neurons in total and nuclear lysates $(p<$ 0.01). Levels of total CRTC1 (WT: $1.0 \pm 0.4 \mathrm{vs} \mathrm{APP}_{\mathrm{Sw}, \text { Ind }}: 0.86 \pm$ 0.14 -fold), CREB (WT: $1.0 \pm 0.1$ vs APP Sw,Ind $_{0}: 9 \pm 0.4$-fold), or phosphorylated CREB (WT: $1.8 \pm 0.6$ vs APP $\mathrm{Sw}_{\mathrm{W}, \text { Ind }}: 2.0 \pm 0.3-$ prompted us to examine the role of $\mathrm{A} \beta$ on calcineurin-mediated CRTC1 activation. Surprisingly, whereas both staurosporine (STS), at doses reported to inhibit SIK and promoting CRTC2 activation [10 nM (Ravnskjaer et al., 2007)], and the active cal- 
fold) were unchanged in $\mathrm{APP}_{\mathrm{Sw} \text {,Ind }}$ neurons (Fig. 3B). To study the biological significance of CRTC1 phosphorylation at Ser151, a phosphorylation site equivalent to CRTC2 Ser 171 (Altarejos et al., 2008), we developed a phosphoSer151-specific CRTC1 antiserum that recognized the endogenous and overexpressed phosphorylated CRTC1 but not a phosphorylation-defective CRTC1 S151A mutant or CRTC2 (Fig. 3C; data not shown). Notably, CRTC1 phosphorylation at Ser151 was significantly increased ( $\sim 2$-fold) in the hippocampus of $\mathrm{APP}_{\mathrm{Sw} \text {,Ind }}$ mice (Fig. 3D). Moreover, both CRTC1 and the active CRTC1 S151A mutant enhanced and reversed CREB transcriptional deficits in $\mathrm{APP}_{\text {Swe,Ind }}$ neurons (Fig. 3E). These results strongly suggested a deficit on calcineurin-mediated CRTC1 dephosphorylation in neurons and brain of $\mathrm{APP}_{\mathrm{Sw}, \mathrm{Ind}}$ mice.

$\mathrm{A} \boldsymbol{\beta}$ reduces calcineurin activity by disrupting $\mathrm{Ca}^{2+}$ influx through L-type calcium channels

Because calcineurin requires $\mathrm{Ca}^{2+}$ for its activation, we next examined the effect of $\mathrm{Ca}^{2+}$ signaling disruption on CRTC1mediated transcription. Blockers of intracellular $\mathrm{Ca}^{2+}$ (BAPTA), $\mathrm{Ca}^{2+}$ influx (EGTA), and $\mathrm{Ca}^{2+}$ mobilization from endoplasmic reticulum (thapsigargin) significantly reduced CRTC1-dependent transcription in cortical neurons (supplemental Fig. 3S, available at www. jneurosci.org as supplemental material). Indeed, calcineurin activity was significantly reduced in hippocampal $(\sim 25 \%)$ and cortical $(\sim 40 \%)$ neurons and adult brain $(\sim 47 \%)$ from $\mathrm{APP}_{\mathrm{Sw}_{\mathrm{w}} \text { Ind }}$ mice (Fig. $4 A$ ). Western blotting analysis revealed unchanged levels of the calcineurin calmodulinbinding catalytic and $\mathrm{Ca}^{2+}$-binding subunits in $\mathrm{APP}_{\mathrm{Sw} \text {,Ind }}$ neurons (Fig. 4B). We then measured cytosolic calcium concentration changes elicited by depolarization and cAMP, which are mediated by $\mathrm{Ca}^{2+}$ influx from L-type voltage-gated calcium channels (VGCCs) and $\mathrm{Ca}^{2+}$ mobilization from intracellular stores. Accordingly, $\mathrm{Ca}^{2+}$ imaging experiments showed that the amplitude of $\mathrm{Ca}^{2+}$ changes elicited by FSK/KCl treatment was significantly reduced in $\mathrm{APP}_{\mathrm{Sw} \text {,Ind }}$ neurons (Fig. $4 C$ ). Similar percentage of control and $\mathrm{APP}_{\mathrm{Sw}, \text { Ind }}$ neurons responded to treatment.

L-type VGCCs greatly contribute to $\mathrm{Ca}^{2+}$-induced gene expression in hippocampal neurons (Murphy et al., 1991; Mintz et al., 1992; West et al., 2001; Cohen and Greenberg, 2008). Indeed, blockers of postsynaptic L-type (verapamil and nimodipine) or presynaptic N/P/Q-type ( $\omega$-conotoxin) VGCCs, but not AMPA (CNQX) or NMDA (MK-801) antagonists, reduced and occluded the effect of $\mathrm{CAMP} / \mathrm{Ca}^{2+}$ on CRTC1 transcription in control and $\mathrm{APP}_{\mathrm{S} \text {,Ind }}$ neurons, respectively (Fig. $4 D$; supplemental Fig. 3S, available at www.jneurosci.org as supplemental material). Accordingly, the specific L-type $\mathrm{Ca}^{2+}$ channel agonists BayK-8644, FPL 64176, and nefiracetam activated and reversed CREB transcrip-
C
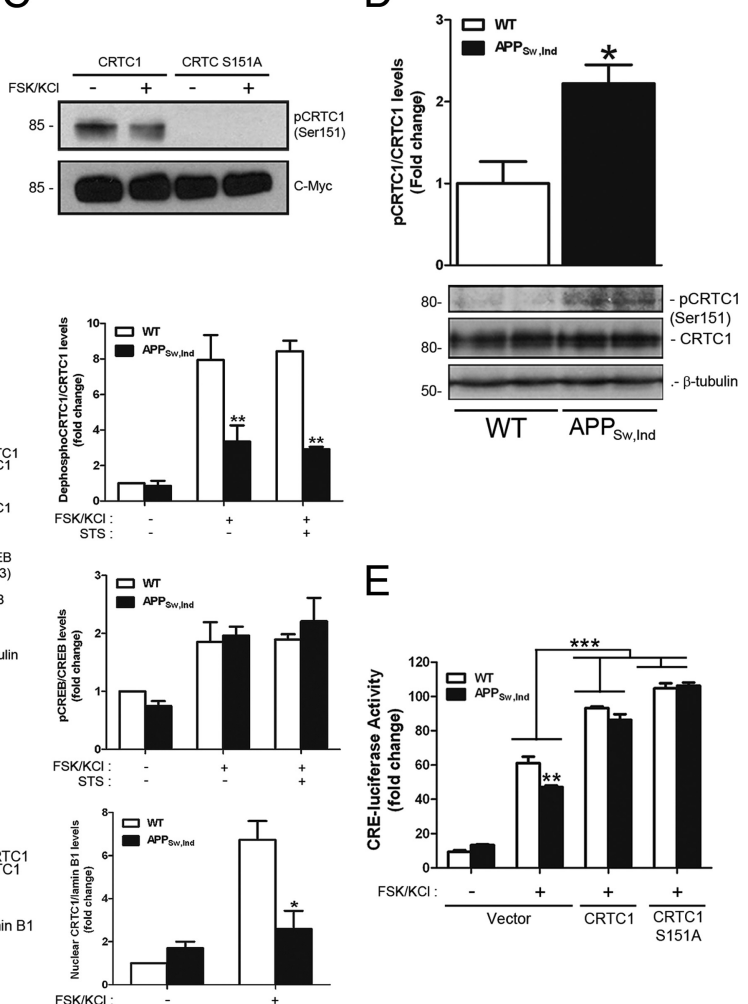

Figure 3. $A \beta$ impairs CRTC1/CREB-dependent transcription by affecting CRTC1 dephosphorylation. $A$, CRE transcriptional ac(bottom blot and me CRTC1 S151A mutant expressed in HEK 293T cells. D, Western blot analysis of phosphorylated CRTC

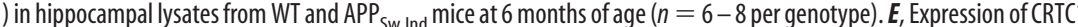
and CRTC1 S151A reverses CRE-transcriptional deficits in $\mathrm{APP}_{\mathrm{SW}_{\mathrm{W}} \text { Ind }}$ neurons. Data represent the mean $\pm \mathrm{SEM}$ of three independent transfections performed in duplicate. ${ }^{*} p<0.05,{ }^{* *} p<0.001,{ }^{* * *} p<0.0001$.

tional deficits in $\mathrm{APP}_{\mathrm{Sw}, \text { Ind }}$ neurons (Fig. 4E). Altogether, these results demonstrated that deficient calcium influx through L-type VGCCs was directly involved in disruption of CRTC1-dependent transcription in $\mathrm{APP}_{\mathrm{Sw}, \text { Ind }}$ neurons.

\section{Disruption of CRTC1-dependent gene expression is} associated with hippocampal-dependent memory deficits in $\mathrm{APP}_{\text {Swe,Ind }}$ transgenic mice

Having seen the critical role of A $\beta$ on CRTC1-mediated transcription, we finally analyzed its effect on memory deficits in $\mathrm{APP}_{\mathrm{Sw}, \text { Ind }}$ transgenic mice at an age (6 months) coinciding with initial $A \beta 40 / A \beta 42$ accumulation (Mucke et al., 2000; España et al., 2010) (data not shown). We used the Morris water maze, a spatial memory task that induces expression of immediate early genes $0.5-1 \mathrm{~h}$ after training (Guzowski et al., 2001). Six-monthold $\mathrm{APP}_{\mathrm{Sw}, \text { Ind }}$ mice required significantly longer latencies and distances to locate the platform during training (two-way ANOVA; latencies: genotype effect, $F_{(1,50)}=19.9$; day effect, $\left.F_{(4,50)}=31.6 ; p<0.0001\right)$. In the probe trial, $\mathrm{APP}_{\mathrm{Sw}, \text { Ind }}$ mice spent significantly less time searching and crossing the target platform than controls (genotype effect: $F_{(1,40)}=5.6$; quadrant effect: $F_{(3,40)}=6.1, p<0.002$ ) (Fig. $5 \mathrm{~A}$ and data not shown). Quantitative real-time RT-PCR analysis revealed a selective reduction of CREB target genes regulated by CRTC1 related to 
A

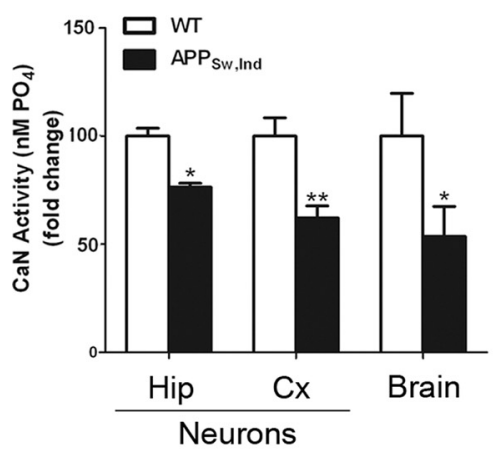

B

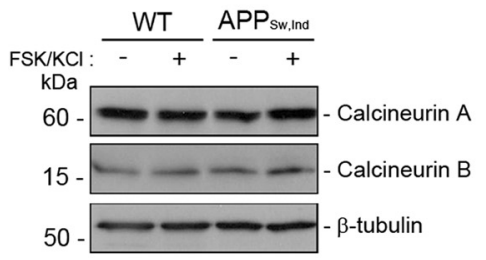

C
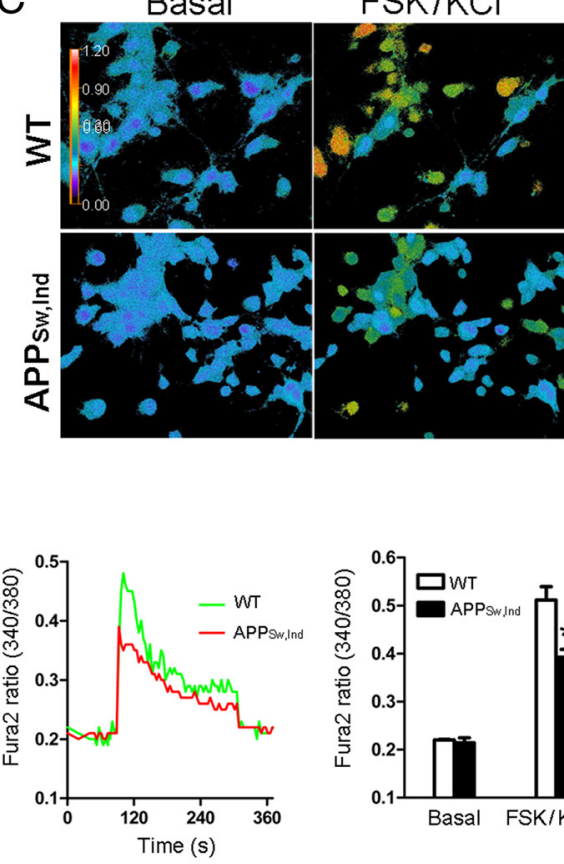

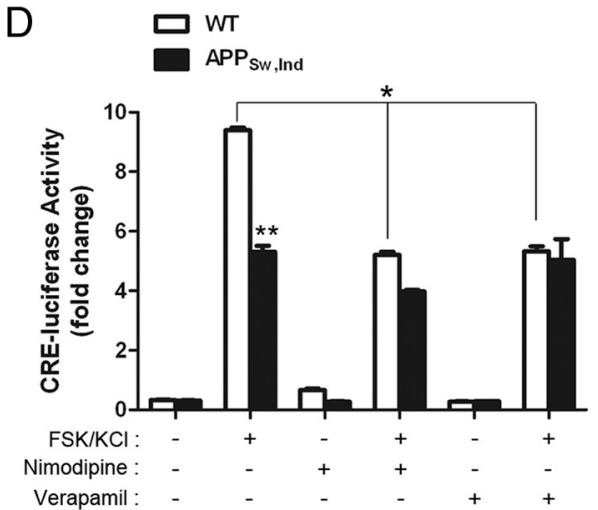

$\mathrm{E}$

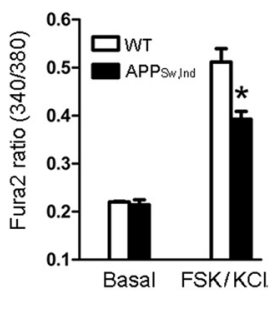

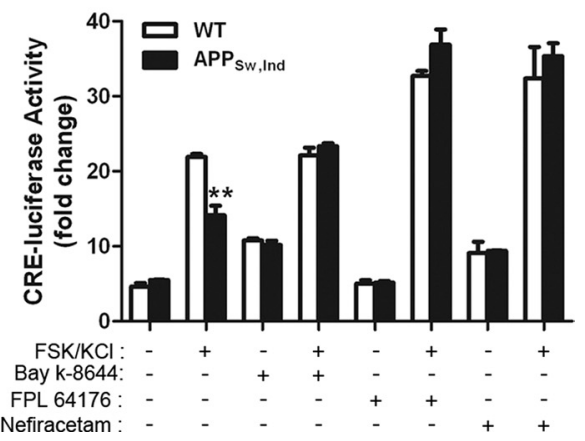

Figure 4. $A \beta$ interferes with calcium-induced CRTC1 activation. $A$, Decreased calcineurin activity in cultured hippocampal (Hip) or cortical (CX) neurons and brain from APP ${ }_{5 w}$,Ind $\operatorname{mice}(n=3$ independent cultures and brains). $\boldsymbol{B}$, Western analysis showing expression of calcineurin in total lysates from WT and APP ${ }_{\text {Sw, Ind }}$ cortical neurons. $\boldsymbol{C}$, Intracellular $\mathrm{Ca}^{2+}$ responses in basal and FSK/KCI conditions. Representative calcium images (top) and traces (bottom left) and the mean of peak amplitudes (bottom right) of control and APP ${ }_{\text {Sw,Ind }}$ neurons are shown. Data represent the mean \pm SEM of three independent cultures per genotype ( $n \geq 15$ cells per culture). $\boldsymbol{D}$, L-type VGCC blockers nimodipine $(5 \mu \mathrm{m})$ and verapamil (100 $\mu \mathrm{m}$ ) mimic and occlude the effect of A $\beta$ on CRE-transcriptional activity in cortical neurons. E, L-type VGCC agonists Bay K-8644 (10 $\mu \mathrm{m}), F P L 64176(5 \mu \mathrm{m})$, and nefiracetam $(5 \mu \mathrm{m})$ increase and reverse CREB-transcriptional deficits in APP Sw, Ind cortical neurons. CRE-luciferase activity was determined as described in Figure 1. ${ }^{*} p<0.05,{ }^{* *} p<0.01$.

memory (c-fos, Bdnf, and Nr4a2) but not to stress (Rgs2) (Fig. 1) (Ravnskjaer et al., 2007) and unchanged CREB genes regulated independently of CRTC1 involved in memory processing (Egr1), cell proliferation (Cyr61), or stress (Fosb and Junb) in the hippocampus of trained $\mathrm{APP}_{\mathrm{Sw}, \text { Ind }}$ mice (Fig. $5 B, C$ ). Reduced expression of $\mathrm{mR}$ NAs was associated with a significant decreased of c-fos and Bdnf protein levels (Fig. 5D,E). These results revealed specific disruption of CRTC1-dependent genes coinciding with $\mathrm{A} \beta$ accumulation and hippocampal-dependent spatial memory deficits in $\mathrm{APP}_{\mathrm{Sw}, \mathrm{Ind}}$ mice.

\section{Discussion}

Gene expression changes in the brain have been suggested to underlie synaptic and cognitive dysfunction during normal and pathological aging (Coleman and Yao, 2003; Berchtold et al., 2008). The molecular mechanisms underlying gene expression changes during memory impairment are largely unknown. In this study, we identified the transcriptional coactivator CRTC1 as mediating the effect of $\mathrm{A} \beta$ on disrupting synaptic coupling to activation of genes required for neuronal plasticity and memory. The temporal coincidence of deregulated CRTC1-dependent transcription and cognitive dysfunction in a mouse model of $\mathrm{AD}$ strongly argues for a role of CRTC1 on mediating memory processing in normal and pathological conditions.

The transcription factor CREB is a key contributor to cAMPand calcium-dependent gene transcription during synaptic development and plasticity (Cohen and Greenberg, 2008; Won and Silva, 2008). CREB signaling requires phosphorylation of CREB on Ser133 by cAMP- and $\mathrm{Ca}^{2+} /$ calmodulin-dependent kinases (Gonzalez and Montminy, 1989; Dash et al., 1991; Sheng et al., 1991). However, CREB phosphorylation is not sufficient to activate gene transcription (Bito et al., 1996; Zhang et al., 2005), requiring the coactivators CBP, p300, and CRTC (Chrivia et al., 1993; Conkright et al., 2003; Ravnskjaer et al., 2007). Our results showing similar increase of CREB phosphorylation by calcium/ cAMP signals in control and $\mathrm{APP}_{\mathrm{Sw}_{\mathrm{w}} \text { Ind }}$ cortical neurons is consistent with previous reports demonstrating unchanged CREB phosphorylation by $\mathrm{A} \beta 42$ in basal or FSK-stimulated mature neurons (Tong et al., 2001; Vitolo et al., 2002; Snyder et al., 2005). By contrast, CREB phosphorylation is decreased in AD brain (Yamamoto-Sasaki et al., 1999) and oligomeric A $\beta 42$ suppresses NMDA- and depolarization-induced CREB phosphorylation in immature neurons (Tong et al., 2001; Ma et al., 2007), an effect that may be due to cAMP/PKA signaling deregulation (Vitolo et al., 2002). Indeed, it was previously shown that $A \beta$ alters hippocampal synaptic plasticity, memory, and synapse morphology through cAMP/PKA-dependent CREB signaling, whereas potentiating this pathway reverses those deficits (Gong et al., 2004, 2006; Smith et al., 2009).

Calcium and cAMP signals do not always cooperate to activate gene expression in response to neuronal activity (Belfield et al., 2006), but they act synergistically on CREB signaling by activating the transcriptional coactivator CRTC (Screaton et al., 2004; Kovács et al., 2007). Consistently, we found deregulation of CRTC1-dependent CREB transcription and reduced $\mathrm{Ca}^{2+}$ re- 

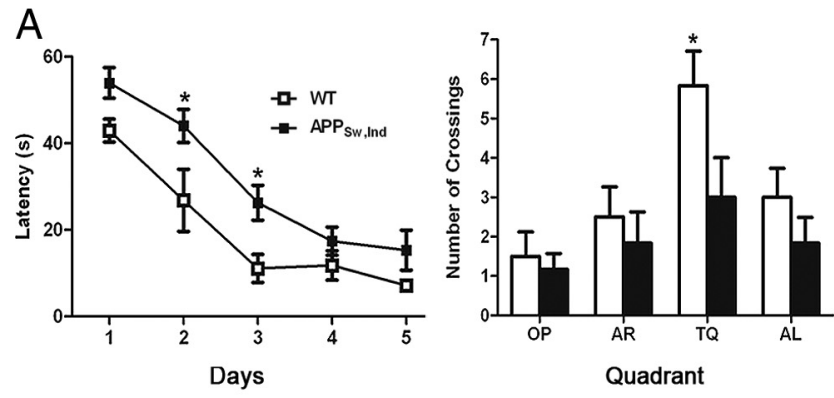

B

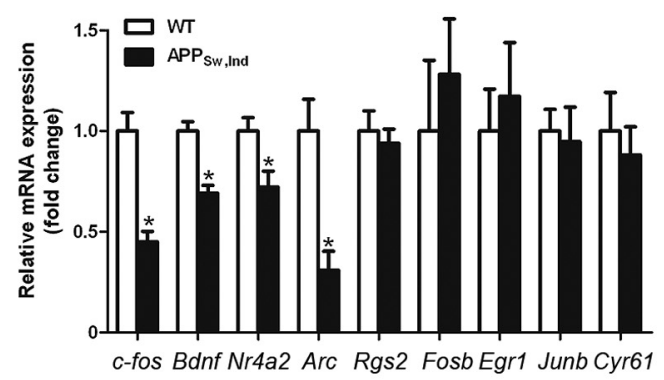

C
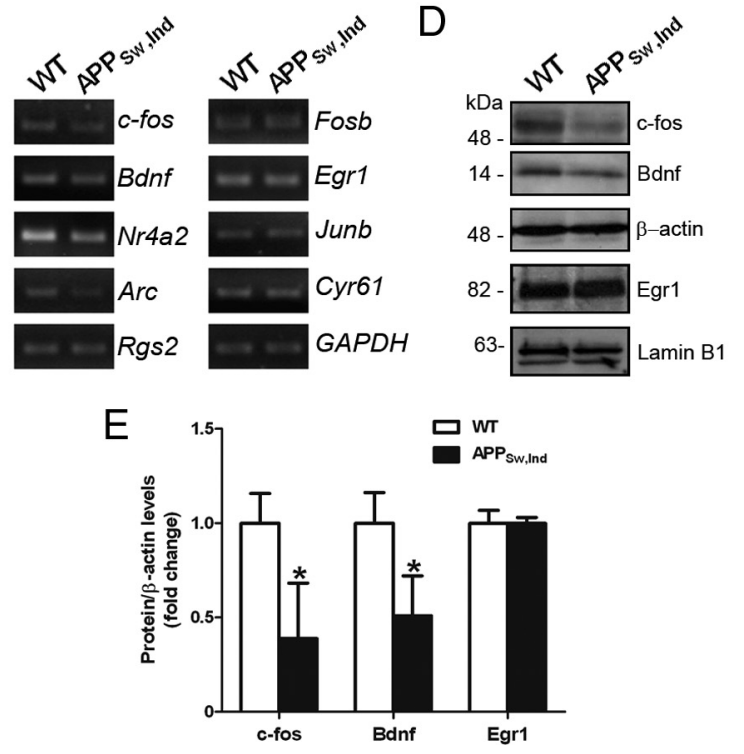

Figure 5. Reduced CRTC1-dependent CREB target genes in the hippocampus of cognitive impaired $\mathrm{APP}_{\mathrm{Sw}_{\mathrm{w}} \text { Ind }}$ mice. $A, \mathrm{APP}_{\mathrm{Sw}, \text { Ind }}$ transgenic mice display learning and spatial memory deficits in the Morris water maze. Six-month-old littermate $A_{S P} P_{S w, I n d}$ and nontransgenic control mice ( $n=6$ per genotype) were trained in the MWM for $5 \mathrm{~d}$. $\mathrm{APP}_{\mathrm{SW}, \text { Ind }}$ mice learnt the task but they required significantly longer latencies to locate the platform (two-way ANOVA; latencies: genotype effect, $F_{(1,50)}=19.9$; day effect, $\left.F_{(4,50)}=31.6 ; p<0.0001\right)$. In the probe trial, $A_{P P_{S w, I n d}}$ transgenic mice spent significantly less time searching and crossing the target quadrant (TQ) platform location than nontransgenic controls. Data represent the mean \pm SEM. ${ }^{*} p<0.05$, compared to the same day during training or the rest of quadrants during the probe trial. OP, Opposite platform; $A R$, adjacent right platform; $A L$, adjacent left platform. $B$, Quantitative analysis of hippocampal mRNA of CREB target genes by real-time RT-PCR. Values were normalized to GAPDH. $n=4-5$ per genotype. C, PCR analysis showing differential expression of CRTC1 target genes in the hippocampus of $A_{P P}{ }_{S_{W} \text {, Ind }}$ mice compared to controls. Bdnf refers to Bdnf IV. D, Western blot images showing reduction of c-fos and Bdnf but not Egr1 in the hippocampus of APP $_{S w, \text { Ind }}$ mice. E, Quantitative analysis of c-fos, Bdnf, and Egr1 protein levels in hippocampus of 6-month-old WT and $A P P_{S w, I n d}$ mice. Data represent the mean \pm SEM. ${ }^{*} p<0.05$.

sponses by naturally secreted $A \beta$ or synthetic $A \beta$ oligomers. These transcriptional deficits are likely attributable to the direct effect of $A \beta$ on CRTC1 because they were prevented by pharmacological or genetic inhibition of $A \beta$ production or by expressing
CRTC1 or CRTC1 S151A but not CREB. Surprisingly, treatment of neurons with Ab20.1 antibody reversed only partially CREtranscriptional deficits, suggesting that both intracellular and extracellular $A \beta$ could contribute to the CRTC1-transcriptional deficits. We therefore propose that deregulation of CRTC1 rather than CREB account for the observed activity-dependent transcriptional deficits in our AD neuronal model.

Our results also provide insights into molecular mechanisms underlying gene expression changes in AD. Activity-dependent gene expression mediated by CREB in excitatory neurons depends on calcium influx through L-type VSCCs or either NMDA or AMPA glutamate receptors (Greer and Greenberg, 2008). Though L-type VGCCs make a minor contribution to synaptic-induced calcium current, they play a critical role in coupling synaptic stimulation to activation of nuclear gene expression (Murphy et al., 1991; Greer and Greenberg, 2008). In agreement with this view, we found that depletion of intracellular calcium and blockers of VGCCs, but not NMDA or AMPA receptor antagonists, reduced significantly CRTC1 transcriptional activity in control neurons, whereas they mimicked the transcriptional defects observed in $\mathrm{APP}_{\mathrm{SW}_{\mathrm{w}} \text {,Ind }}$ neurons. Our results also agree with previous reports showing that $B d n f, c-f o s$, Junb, Egr-1, and Fosb are primarily activated by calcium entry through L-type VSCCs rather than NMDA or N-type calcium channels (Murphy et al., 1991; Ghosh et al., 1994). Studies in mice lacking the Cav1.2 channel suggest a role of L-type $\mathrm{Ca}^{2+}$ channels on NMDAR-independent hippocampal LTP and CREB transcription (Moosmang et al., 2005). Because A $\beta$ depresses excitatory synaptic transmission through AMPA and NMDA receptors (Snyder et al., 2005; Hsieh et al., 2006; Dewachter et al., 2009), one possibility is that $\mathrm{A} \beta$ modulates differentially glutamatergic signaling depending on its levels (Puzzo et al., 2008).

The finding that agonists of L-type $\mathrm{Ca}^{2+}$ channels reversed the CREB transcriptional deficits in $\mathrm{APP}_{\mathrm{Sw} \text {,Ind }}$ cortical neurons strongly implicates altered calcium influx through these channels on the A $\beta$-induced CRTC1 transcriptional deficits. Indeed, calcium imaging analysis demonstrated decreased intracellular $\mathrm{Ca}^{2+}$ mobilization in response to depolarization and cAMP signals in $\mathrm{APP}_{\mathrm{Sw}, \text { Ind }}$ neurons. Although toxic $\mathrm{A} \beta$ is known to elevate $\mathrm{Ca}^{2+}$ responses, $\mathrm{A} \beta$ reduces $\mathrm{P} / \mathrm{Q}$-type calcium currents and spontaneous $\mathrm{Ca}^{2+}$ responses in $\sim 30 \%$ of cortical neurons in APP mice (Busche et al., 2008; Nimmrich et al., 2008). One of the consequences of reduced calcium responses by $\mathrm{A} \beta$ may be an impairment of calcineurin activity (Fig. 4) (Lian et al., 2001; Celsi et al., 2007), which in turn may result in decreased L-type $\mathrm{Ca}^{2+}$ channel function (Norris et al., 2002; Tandan et al., 2009). Consistent with an essential role of calcineurin on depolarizationinduced CREB-dependent transcription and CRTC1 function (Kingsbury et al., 2007; Kovács et al., 2007), CREB transcriptional activity and CRTC1 dephosphorylation induced by calcium and cAMP signals were fully blocked by calcineurin inhibitors, whereas the active $\Delta \mathrm{CnA}$ mutant efficiently reversed the transcriptional deficits in $\mathrm{APP}_{\mathrm{Sw} \text {,Ind }}$ neurons. In support of a role of altered dephosphorylation of CRTC1 on CRE-transcriptional deficits, we found that SIK inhibition was unable to reverse efficiently CREB transcription or CRTC1 dephosphorylation in $\mathrm{APP}_{\mathrm{Sw}, \mathrm{Ind}}$ neurons. Other explanations for reduced calcium responses induced by depolarization and forskolin in $\mathrm{APP}_{\mathrm{Sw} \text {,Ind }}$ neurons, including deficient PKA-mediated L-type $\mathrm{Ca}^{2+}$ channel function, cannot be ruled out (Vitolo et al., 2002; Davare and Hell, 2003).

It has been postulated that activity-dependent gene expression plays an essential role in plasticity mechanisms required for memory processing (Guzowski et al., 2005). Neuronal activity and memory training induce expression of $B d n f, c-f o s, J u n b$, 
Egr-1, and Fosb (Murphy et al., 1991; Worley et al., 1993; Guzowski et al., 2001). Notably, we found that deregulation on CRTC1-dependent genes, including $c$-fos, Bdnf, and Nr4a2, coincided with the first long-term spatial memory deficits in $\mathrm{APP}_{\mathrm{Sw}, \text { Ind }}$ mice (España et al., 2010), suggesting that these events are tightly linked early in the disease process. Notably, reduced $c$-fos levels were recently associated with learning and memory deficits in APP transgenic mice (Palop et al., 2003; Dewachter et al., 2009), whereas BDNF is decreased in brains of AD patients and transgenic mice (Phillips et al., 1991; Dickey et al., 2003; Palop et al., 2003). In this regard, $B d n f I V$, which is induced by calcium influx during neuronal activity and is downregulated by $\mathrm{A} \beta$ (Tong et al., 2001; Garzon and Fahnestock, 2007), is particularly important. Our finding that disruption of $B d n f I V$ and $c$-fos expression is mediated by deregulation of CRTC1 in APP transgenic mice provides the first reported molecular mechanism underlying deregulation of $\mathrm{c}$-fos and $\mathrm{BDNF}$ signaling in $\mathrm{AD}$.

In conclusion, our finding that $\mathrm{A} \beta$ disrupts expression of CRTC1 target genes essential for memory processing provides a potential mechanism contributing to cognitive decline in AD. These results may have important therapeutic implications in $\mathrm{AD}$. Indeed, reduced levels of BDNF in CSF were recently associated with age-related cognitive decline (G. Li et al., 2009), whereas BDNF exerts substantial protective effects on neuronal survival and memory circuits in rodent and primate models of AD (Nagahara et al., 2009). Similarly, neural stem cells transplanted in the hippocampus of 3xTg-AD mice enhance synaptic density and improve cognitive function through BDNF (BlurtonJones et al., 2009). Importantly, agents that activate the PKA/ CREB signaling pathway, such as rolipram, ameliorate hippocampal-dependent memory deficits and synapse loss in APP transgenic mice (Gong et al., 2004; Smith et al., 2009). Therefore, understanding the molecular mechanisms regulating CRTC1dependent signaling and gene responses to therapeutic drugs may provide new targets for memory enhancement in cognitive disorders.

\section{References}

Altar CA, Vawter MP, Ginsberg SD (2009) Target identification for CNS diseases by transcriptional profiling. Neuropsychopharmacology 34: $18-54$.

Altarejos JY, Goebel N, Conkright MD, Inoue H, Xie J, Arias CM, Sawchenko PE, Montminy M (2008) The Crebl coactivator Crtcl is required for energy balance and fertility. Nat Med 14:1112-1117.

Belfield JL, Whittaker C, Cader MZ, Chawla S (2006) Differential effects of $\mathrm{Ca}^{2+}$ and cAMP on transcription mediated by MEF2D and CAMPresponse element-binding protein in hippocampal neurons. J Biol Chem 281:27724-27732.

Berchtold NC, Cribbs DH, Coleman PD, Rogers J, Head E, Kim R, Beach T, Miller C, Troncoso J, Trojanowski JQ, Zielke HR, Cotman CW (2008) Gene expression changes in the course of normal brain aging are sexually dimorphic. Proc Natl Acad Sci U S A 105:15605-15610.

Bito H, Deisseroth K, Tsien RW (1996) CREB phosphorylation and dephosphorylation: $\mathrm{a} \mathrm{Ca}(2+)$ - and stimulus duration-dependent switch for hippocampal gene expression. Cell 87:1203-1214.

Bittinger MA, McWhinnie E, Meltzer J, Iourgenko V, Latario B, Liu X, Chen $\mathrm{CH}$, Song C, Garza D, Labow M (2004) Activation of cAMP response element-mediated gene expression by regulated nuclear transport of TORC proteins. Curr Biol 14:2156-2161.

Blurton-Jones M, Kitazawa M, Martinez-Coria H, Castello NA, Müller FJ, Loring JF, Yamasaki TR, Poon WW, Green KN, LaFerla FM (2009) Neural stem cells improve cognition via BDNF in a transgenic model of Alzheimer disease. Proc Natl Acad Sci U S A 106:13594-13599.

Bourtchuladze R, Frenguelli B, Blendy J, Cioffi D, Schutz G, Silva AJ (1994) Deficient long-term memory in mice with a targeted mutation of the c-AMP-responsive element binding protein. Cell 79:59-68.

Busche MA, Eichhoff G, Adelsberger H, Abramowski D, Wiederhold KH,
Haass C, Staufenbiel M, Konnerth A, Garaschuk O (2008) Clusters of hyperactive neurons near amyloid plaques in a mouse model of Alzheimer's disease. Science 321:1686-1689.

Celsi F, Svedberg M, Unger C, Cotman CW, Carrì MT, Ottersen OP, Nordberg A, Torp R (2007) $\beta$-Amyloid causes downregulation of calcineurin in neurons through induction of oxidative stress. Neurobiol Dis 26:342-352.

Chrivia JC, Kwok RPS, Lamb N, Hagiwara M, Montminy MR, Goodman RH (1993) Phosphorylated CREB binds specifically to the nuclear protein CBP. Nature 365:855-859.

Cohen S, Greenberg ME (2008) Communication between the synapse and the nucleus in neuronal development, plasticity, and disease. Annu Rev Cell Dev Biol 24:183-209.

Coleman PD, Yao PJ (2003) Synaptic slaughter in Alzheimer's disease. Neurobiol Aging 24:1023-1027.

Conkright MD, Canettieri G, Screaton R, Guzman E, Miraglia L, Hogenesch JB, Montminy M (2003) TORCs: transducers of regulated CREB activity. Mol Cell 12:413-423.

Dash PK, Karl KA, Colicos MA, Prywes R, Kandel ER (1991) cAMP response element-binding protein is activated by $\mathrm{Ca} 2+/$ calmodulin- as well as cAMP-dependent protein kinase. Proc Natl Acad Sci USA 88:5061-5065.

Davare MA, Hell JW (2003) Increased phosphorylation of the neuronal L-type $\mathrm{Ca}^{2+}$ channel $\mathrm{Ca}(\mathrm{v}) 1.2$ during aging. Proc Natl Acad Sci U S A 100:16018-16023.

Dewachter I, Filipkowski RK, Priller C, Ris L, Neyton J, Croes S, Terwel D, Gysemans M, Devijver H, Borghgraef P, Godaux E, Kaczmarek L, Herms J, Van Leuven F (2009) Deregulation of NMDA-receptor function and down-stream signaling in APP[V717I] transgenic mice. Neurobiol Aging 30:241-256.

Dickey CA, Loring JF, Montgomery J, Gordon MN, Eastman PS, Morgan D (2003) Selectively reduced expression of synaptic plasticity-related genes in amyloid precursor protein + presenilin-1 transgenic mice. J Neurosci 23:5219-5226.

España J, Giménez-Llort L, Valero J, Miñano A, Rábano A, RodriguezAlvarez J, LaFerla FM, Saura CA (2010) Intraneuronal $\beta$-amyloid accumulation in the amygdala enhances fear and anxiety in Alzheimer's disease transgenic mice. Biol Psychiatry 67:513-521.

Garzon DJ, Fahnestock M (2007) Oligomeric amyloid decreases basal levels of brain-derived neurotrophic factor (BDNF) mRNA via specific downregulation of BDNF transcripts IV and V in differentiated human neuroblastoma cells. J Neurosci 27:2628-2635.

Ghosh A, Carnahan J, Greenberg ME (1994) Requirement for BDNF in activity-dependent survival of cortical neurons. Science 263:1618-1623.

Giménez-Llort L, Blázquez G, Cañete T, Johansson B, Oddo S, Tobeña A, LaFerla FM, Fernández-Teruel A (2007) Modeling behavioral and neuronal symptoms of Alzheimer's disease in mice: a role for intraneuronal amyloid. Neurosci Biobehav Rev 31:125-147.

Gong B, Vitolo OV, Trinchese F, Liu S, Shelanski M, Arancio O (2004) Persistent improvement in synaptic and cognitive functions in an Alzheimer mouse model after rolipram treatment. J Clin Invest 114:1624-1634.

Gong B, Cao Z, Zheng P, Vitolo OV, Liu S, Staniszewski A, Moolman D, Zhang H, Shelanski M, Arancio O (2006) Ubiquitin hydrolase Uch-L1 rescues $\beta$-amyloid-induced decreases in synaptic function and contextual memory. Cell 126:775-788.

Gonzalez GA, Montminy MR (1989) Cyclic AMP stimulates somatostatin gene transcription by phosphorylation of CREB at serine 133. Cell 59:675-680.

Greer PL, Greenberg ME (2008) From synapse to nucleus: calciumdependent gene transcription in the control of synapse development and function. Neuron 59:846-860.

Guardia-Laguarta C, Coma M, Pera M, Clarimón J, Sereno L, Agulló JM, Molina-Porcel L, Gallardo E, Deng A, Berezovska O, Hyman BT, Blesa R, Gómez-Isla T, Lleó A (2009) Mild cholesterol depletion reduces amyloid- $\beta$ production by impairing APP trafficking to the cell surface. J Neurochem 110:220-230.

Guzowski JF, Setlow B, Wagner EK, McGaugh JL (2001) Experiencedependent gene expression in the rat hippocampus after spatial learning: a comparison of the immediate-early genes Arc, c-fos, and zif268. J Neurosci 21:5089-5098.

Guzowski JF, Timlin JA, Roysam B, McNaughton BL, Worley PF, Barnes CA 
(2005) Mapping behaviorally relevant neural circuits with immediateearly gene expression. Curr Opin Neurobiol 15:599-606.

Hsieh H, Boehm J, Sato C, Iwatsubo T, Tomita T, Sisodia S, Malinow R (2006) AMPAR removal underlies A $\beta$-induced synaptic depression and dendritic spine loss. Neuron 52:831-843.

Iourgenko V, Zhang W, Mickanin C, Daly I, Jiang C, Hexham JM, Orth AP, Miraglia L, Meltzer J, Garza D, Chirn GW, McWhinnie E, Cohen D, Skelton J, Terry R, Yu Y, Bodian D, Buxton FP, Zhu J, Song C, et al. (2003) Identification of a family of cAMP response element-binding protein coactivators by genome-scale functional analysis in mammalian cells. Proc Natl Acad Sci U S A 100:12147-12152.

Janknecht R, Wells NJ, Hunter T (1998) TGF-beta-stimulated cooperation of smad proteins with the coactivators $\mathrm{CBP} / \mathrm{p} 300$. Genes Dev 12:2114-2119.

Kandel ER (2001) The molecular biology of memory storage: a dialogue between genes and synapses. Science 294:1030-1038.

Kingsbury TJ, Bambrick LL, Roby CD, Krueger BK (2007) Calcineurin activity is required for depolarization-induced, CREB-dependent gene transcription in cortical neurons. J Neurochem 103:761-770.

Klein WL (2002) A $\beta$ toxicity in Alzheimer's disease: globular oligomers (ADDLs) as new vaccine and drug targets. Neurochem Int 41:345-352.

Kovács KA, Steullet P, Steinmann M, Do KQ, Magistretti PJ, Halfon O, Cardinaux JR (2007) TORC1 is a calcium- and cAMP-sensitive coincidence detector involved in hippocampal long-term synaptic plasticity. Proc Natl Acad Sci U S A 104:4700-4705.

Li G, Peskind ER, Millard SP, Chi P, Sokal I, Yu CE, Bekris LM, Raskind MA, Galasko DR, Montine TJ (2009) Cerebrospinal fluid concentration of brain-derived neurotrophic factor and cognitive function in nondemented subjects. PLoS ONE 4:e5424.

Li S, Zhang C, Takemori H, Zhou Y, Xiong ZQ (2009) TORC1 regulates activity-dependent CREB-target gene transcription and dendritic growth of developing cortical neurons. J Neurosci 29:2334-2343.

Lian Q, Ladner CJ, Magnuson D, Lee JM (2001) Selective changes of calcineurin (protein phosphatase 2B) activity in Alzheimer's disease cerebral cortex. Exp Neurol 167:158-165.

Ma QL, Harris-White ME, Ubeda OJ, Simmons M, Beech W, Lim GP, Teter B, Frautschy SA, Cole GM (2007) Evidence of Abeta- and transgenedependent defects in ERK-CREB signaling in Alzheimer's models. J Neurochem 103:1594-1607.

Mayr B, Montminy M (2001) Transcriptional regulation by the phosphorylation-dependent factor CREB. Nat Rev Mol Cell Biol 2:599-609.

Mintz IM, Adams ME, Bean BP (1992) P-type calcium channels in rat central and peripheral neurons. Neuron 9:85-95.

Moosmang S, Haider N, Klugbauer N, Adelsberger H, Langwieser N, Müller J, Stiess M, Marais E, Schulla V, Lacinova L, Goebbels S, Nave KA, Storm DR, Hofmann F, Kleppisch T (2005) Role of hippocampal Cav1.2 $\mathrm{Ca}^{2+}$ channels in NMDA receptor-independent synaptic plasticity and spatial memory. J Neurosci 25:9883-9892.

Mucke L, Masliah E, Yu GQ, Mallory M, Rockenstein EM, Tatsuno G, Hu K, Kholodenko D, Johnson-Wood K, McConlogue L (2000) High-level neuronal expression of $\mathrm{A} \beta_{1-42}$ in wild-type human amyloid protein precursor transgenic mice: synaptotoxicity without plaque formation. J Neurosci 20:4050-4058.

Murphy TH, Worley PF, Baraban JM (1991) L-type voltage-sensitive calcium channels mediate synaptic activation of immediate early genes. Neuron 7:625-635.

Nagahara AH, Merrill DA, Coppola G, Tsukada S, Schroeder BE, Shaked GM, Wang L, Blesch A, Kim A, Conner JM, Rockenstein E, Chao MV, Koo EH, Geschwind D, Masliah E, Chiba AA, Tuszynski MH (2009) Neuroprotective effects of brain-derived neurotrophic factor in rodent and primate models of Alzheimer's disease. Nat Med 15:331-337.

Nimmrich V, Grimm C, Draguhn A, Barghorn S, Lehmann A, Schoemaker H, Hillen H, Gross G, Ebert U, Bruehl C (2008) Amyloid $\beta$ oligomers $\left(\mathrm{A} \beta_{1-42}\right.$ globulomer) suppress spontaneous synaptic activity by inhibition of P/Q-type calcium currents. J Neurosci 28:788-797.

Norris CM, Blalock EM, Chen KC, Porter NM, Landfield PW (2002) Calcineurin enhances L-type $\mathrm{Ca}(2+)$ channel activity in hippocampal neurons: increased effect with age in culture. Neuroscience 110:213-225.

Oddo S, Vasilevko V, Caccamo A, Kitazawa M, Cribbs DH, LaFerla FM (2006) Reduction of soluble abeta and tau, but not soluble abeta alone, ameliorates cognitive decline in transgenic mice with plaques and tangles. J Biol Chem 281:39413-39423.

O’Keefe SJ, Tamura J, Kincaid RL, Tocci MJ, O’Neill EA (1992) FK-506- and CsA-sensitive activation of a interleukin-2 promoter by calcineurin. Nature 357:692-694.

Palop JJ, Jones B, Kekonius L, Chin J, Yu GQ, Raber J, Masliah E, Mucke L (2003) Neuronal depletion of calcium-dependent proteins in the dentate gyrus is tightly linked to Alzheimer's disease-related cognitive deficits. Proc Natl Acad Sci U S A 100:9572-9577.

Phillips HS, Hains JM, Armanini M, Laramee GR, Johnson SA, Winslow JW (1991) BDNF mRNA is decreased in the hippocampus of individuals with Alzheimer's disease. Neuron 7:695-702.

Puzzo D, Privitera L, Leznik E, Fà M, Staniszewski A, Palmeri A, Arancio O (2008) Picomolar amyloid- $\beta$ positively modulates synaptic plasticity and memory in hippocampus. J Neurosci 28:14537-14545.

Ravnskjaer K, Kester H, Liu Y, Zhang X, Lee D, Yates JR 3rd, Montminy M (2007) Cooperative interactions between CBP and TORC2 confer selectivity to CREB target gene expression. EMBO J 26:2880-2889.

Saura CA, Chen G, Malkani S, Choi SY, Takahashi RH, Zhang D, Gouras GK, Kirkwood A, Morris RG, Shen J (2005) Conditional inactivation of presenilin-1 prevents amyloid accumulation and temporarily rescues contextual and spatial working memory impairments in amyloid precursor protein transgenic mice. J Neurosci 25:6755-6764.

Screaton RA, Conkright MD, Katoh Y, Best JL, Canettieri G, Jeffries S, Guzman E, Niessen S, Yates JR 3rd, Takemori H, Okamoto M, Montminy M (2004) The CREB coactivator TORC2 functions as a calcium- and cAMP sensitive coincidence detector. Cell 119:61-74.

Selkoe DJ (2002) Alzheimer's disease is a synaptic failure. Science 298: 789-791.

Sheng M, Thompson MA, Greenberg ME (1991) CREB: a $\mathrm{Ca}^{2+}$-regulated transcription factor phosphorylated by calmodulin-dependent kinases. Science 252:1427-1430.

Smith DL, Pozueta J, Gong B, Arancio O, Shelanski M (2009) Reversal of long-term dendritic spine alterations in Alzheimer disease models. Proc Natl Acad Sci U S A 106:16877-16882.

Snyder EM, Nong Y, Almeida CG, Paul S, Moran T, Choi EY, Nairn AC, Salter MW, Lombroso PJ, Gouras GK, Greengard P (2005) Regulation of NMDA receptor trafficking by amyloid- $\beta$. Nat Neurosci 8:1051-1058.

Tandan S, Wang Y, Wang TT, Jiang N, Hall DD, Hell JW, Luo X, Rothermel BA, Hill JA (2009) Physical and functional interaction between calcineurin and the cardiac L-type $\mathrm{Ca}^{2+}$ channel. Circ Res 105:51-60.

Tong L, Thornton PL, Balazs R, Cotman CW (2001) $\beta$-amyloid-(1-42) impairs activity-dependent cAMP-response element-binding protein signaling in neurons at concentrations in which cell survival is not compromised. J Biol Chem 276:17301-17306.

Vitolo OV, Sant'Angelo A, Costanzo V, Battaglia F, Arancio O, Shelanski M (2002) Amyloid $\beta$-peptide inhibition of the PKA/CREB pathway and long-term potentiation: reversibility by drugs that enhance cAMP signaling. Proc Natl Acad Sci U S A 99:13217-13221.

West AE, Chen WG, Dalva MB, Dolmetsch RE, Kornhauser JM, Shaywitz AJ, Takasu MA, Tao X, Greenberg ME (2001) Calcium regulation of neuronal gene expression. Proc Natl Acad Sci U S A 98:11024-11031.

Won J, Silva AJ (2008) Molecular and cellular mechanisms of memory allocation in neuronetworks. Neurobiol Learn Mem 89:285-292.

Worley PF, Bhat RV, Baraban JM, Erickson CA, McNaughton BL, Barnes CA (1993) Thresholds for synaptic activation of transcription factors in hippocampus: correlation with long-term enhancement. J Neurosci 13:4776-4786.

Yamamoto-Sasaki M, Ozawa H, Saito T, Rösler M, Riederer P (1999) Impaired phosphorylation of cyclic AMP response element binding protein in the hippocampus of dementia of the Alzheimer type. Brain Res 824:300-303.

Zhang X, Odom DT, Koo SH, Conkright MD, Canettieri G, Best J, Chen H, Jenner R, Herbolsheimer E, Jacobsen E, Kadam S, Ecker JR, Emerson B, Hogenesch JB, Unterman T, Young RA, Montminy M (2005) Genomewide analysis of cAMP-response element binding protein occupancy, phosphorylation, and target gene activation in human tissues. Proc Natl Acad Sci U S A 102:4459-4464.

Zhou Y, Wu H, Li S, Chen Q, Cheng XW, Zheng J, Takemori H, Xiong ZQ (2006) Requirement of TORC1 for late-phase long-term potentiation in the hippocampus. PLoS ONE 1:e16. 